\title{
Türk Eğitim Vakfı Bursu Verilecek Uygun Adayların AHP ve TOPSIS Yöntemi Kullanılarak Belirlenmesi: Mehmet Akif Ersoy Üniversitesi Eğitim Fakültesi Örneği
}

Determination of Suitable Candidates for Turkish Education Foundation Scholarship by using AHP and TOPSIS Method: Mehmet Akif Ersoy University Faculty of Education Example

\author{
İhsan PENÇE ${ }^{*}$, Leyla TARHAN² ${ }^{2}$ Özlem ÇETINKAYA BOZKURT ${ }^{3}$ \\ 'Yrd. Doç. Dr., Mehmet Akif Ersoy Üniversitesi, ZTYO, Yönetim Bilișim Sistemleri Bölümü \\ ${ }^{2}$ Mehmet Akif Ersoy Üniversitesi, Sosyal Bilimler Enstitüsü \\ ${ }^{3}$ Doç. Dr., Mehmet Akif Ersoy Üniversitesi, Bucak İșletme Fakültesi, İșletme Bölümü
}

Geliș Tarihi/Received: 18.08.2017

Kabul Tarihi/Accepted: 19.09.2017

Araștırma Makalesi/Research Article

\begin{abstract}
There are institutions and organizations established in our country that aim to support students, who are experiencing difficulties due to successful but material shortcomings, in order to continue their education more easily. Decision-making process is difficult for decision-makers because application of scholarship and evaluation process take time and it is troublesome and there are subjective factors. In this study, Mehmet Akif Ersoy University, Faculty of Education has used multi criteria decision making methods to evaluate the applicants more effectively who applied to receive scholarships from the Turkish Education Foundation. The AHP and TOPSIS methods were used to select the students who will be awarded the scholarship among the 27 students in the application, and the 3 most suitable candidates were determined according to their relative affinity values. By means of multi-criteria decision-making methods, the selection process for the institutions and organizations could be made easier. The results obtained show the feasibility of the method for the institutions and institutions providing the scholarship and it is possible to transfer the election period online.
\end{abstract}

\section{Keywords}

Scholarship choice, Multi-criteria decision making, AHP, TOPSIS

* Sorumlu yazar/Corresponding author E-mail/e-ileti: ihsanpence@mehmetakif.edu.tr

\section{ÖZET}

Ülkemizde yükseköğrenim gören başarılı fakat maddi yetersizlikler nedeniyle zorluklar yașayan öğrencilere, eğitimlerini daha rahat sürdürmelerine destek olmak amacıyla olușturulan kurum ve kurulușlar bulunmaktadır. Burs bașvuru ve değerlendirme ișlemlerinin vakit alması, zahmetli olması ve subjektif etkenler bulunması sebebiyle karar verme süreci karar vericiler için zor olmaktadır. Bu çalıșmada Mehmet Akif Ersoy Üniversitesi Eğitim Fakültesine Türk Eğitim Vakfından burs almak için bașvuruda bulunan öğrencileri daha etkin değerlendirmek amacıyla çok kriterli karar verme yöntemleri kullanılmıștır. Bașvuruda bulunan 27 öğrenci arasından burs verilecek öğrencilerin seçimi için AHP ve TOPSIS yöntemleri kullanılmış olup, en uygun 3 aday göreli yakınlık değerlerine göre belirlenmiștir. Çok kriterli karar verme yöntemleri sayesinde kurum ve kurulușlar için sıkıntılı olan seçim süreci daha kolay bir șekilde yapılabilmiștir. Elde edilen sonuçlar yöntemin burs veren kurum ve kurulușlar için uygulanabilirliğini göstermiș olup seçim sürecinin online ortama aktarılması sağlanabilir.

\section{Anahtar kelimeler}

Burs verilecek öğrenci seçimi, çok kriterli karar verme, AHP, TOPSIS 


\section{Giriș}

Dünya, bilginin öneminin giderek arttığı bir yer haline gelmiștir. Bilginin elde edildiği merkezler olan üniversiteler bireylerin yetiștirildiği yerlerdir. Ülkemizde 2016 yılı itibariyle 111 devlet üniversitesi bulunmakta olup bu üniversitelerde öğrenim gören toplam 6.137.014 öğrenci bulunmaktadır (YÖK, 2016). Üniversite eğitimi almanın maliyetli olması nedeniyle Türkiye'de pek çok öğrenci burs veren kurum ve kuruluşlara bașvuru yapmakta olup her bir kurulușun burs verilecek öğrenciyi belirlemede kendilerine ait farklı kriterleri bulunmaktadır. Öğrenciler aldıkları burslar sayesinde eğitimlerini daha rahat bir șekilde sürdürmekte derslerindeki başarı durumları da buna bağlı olarak etkilenmektedir.

Ülkemizin burs veren kurulușlarından biri olan Türk Eğitim Vakfı (TEV) bursiyer seçimi ișlemlerinde burs verilecek okulları ve her okul için burs alacak öğrenci sayısını kendisi belirlemektedir. TEV adayların bașvuru tarihleri ile mülakat yapılacak yer ve saati, üniversiteler aracilığıyla ve kendisine ait internet sayfasından öğrencilere duyurmaktadır. Her okul için okul yönetimi tarafından belirlenen burs sorumluları ile birlikte TEV sorumlusunun da yer aldığı komisyon, öğrencileri tek tek mülakata alarak belli kriterlere göre değerlendirme yapmaktadır. Burs komisyon üyeleri kontenjan sayısını da göz önünde bulundurarak mülakat esnasında sıralama yapıp öğrencileri objektif ve tarafsız bir șekilde değerlendirirler. Gerçekleștirilen bu değerlendirme ve elemeler, ilgili burs için bașvuruda bulunan aday öğrencilerin fazlalığına ve burs verilecek okul sayısına bağlı olarak değișmekte olup komisyon üyelerinin emek ve zamanını alan bir süreçtir. Bu durum öğrencilerin kendi sıraları gelene kadar uzun bir süre beklemelerine de sebep olmakla birlikte hem komisyon üyeleri için hem de öğrenciler için stresli bir ortam olușturmaktadır. Seçim süreci insan performansına ve düșüncesine bağlı olduğu için ilerleyen saatlerde komisyon üyeleri objektif kararlarında zorlanmaya bașlayıp yanlıs karar verme gibi olumsuz durumlar gerçekleșebilmektedir.

AHP-TOPSIS yöntemi kullanılan bazı çalıșmalar incelendiğinde; Saat (2000) çalıșmasında, karar verme așamasında etkili olan hem niceliksel hem de niteliksel karar kriterlerinin kullanılabildiğini, yeni kriterlerin eklenip çıkarılabildiği esnek bir yapıya sahip olduğu için AHP yöntemi ile çözüme ulaşılabileceğini örneklendirme yaparak açıklamıștır. Dağdeviren vd. (2004) çalıșmalarında, bir elektrik ișletmesinde farklı iş süreçlerinin değerlendirilmesi sonrasında dengeli bir ücret yapısı belirlemek amacı ile AHP yöntemini kullanmıșlar ve iș değerlendirme sürecinde, iș değerlendirme faktörlerini belirlemiș ve bu faktörlerin ağırlıklarını hesaplamıșlardır. Erdem Hacıköylü (2006) yüksek lisans tezi çalıșmasında, Anadolu Üniversitesi'nde barınma ve beslenme yardımı verilecek öğrencilerin belirlenmesi sürecinde, AHP yöntemini kullanarak öğrenci seçimini ele almıș ve seçimi gerçekleștirmiștir. Özyörük ve Özcan (2008) Otomotiv sektöründeki bir șirketin tedarikçi seçiminde sübjektif bazı değerleri de ölçülebilir hale getirerek AHP yöntemini uygulamış ve problemin çözümünü MS Exel'de gerçekleștirmiştir. Gülenç ve Aydın Bilgin (2010) İmalat sektöründeki bir ișletmenin giriș kapısı yenilenmesi ile ilgili yatırım kararını AHP yöntemi ile ele alarak çözüme ulaștırdıkları görülmektedir. Supçiller ve Çapraz (2011) oluklu mukavva kutu üreticisi bir firma için kâğıt tedarikçilerinin seçilmesi sürecinde, AHP ve TOPSIS yöntemlerini uygulayarak mevcut tedarikçileri arasından firma için en uygun tedarikçi seçiminin gerçekleștirilmesi üzerine çalıșmıșlardır. Kutlu vd. (2012) çalıșmalarında çok ölçütlü karar 
verme yöntemlerinden AHP ve TOPSIS kullanarak öğrencilerin seçmeli ders seçimleri konusu üzerinde çalıșmıșlardır. Çalıșmada seçmeli ders seçiminde etkili olacak kriterler öğrencilere uygulanan anket yöntemiyle belirlenmiș ve balık kılçığı diyagramı ile seçenekleri düșürerek, AHP yöntemi ile kriterlerin ağırlıklarını bulmuşlar ve TOPSIS yöntemi ile sonuca ulașmışlardır. Abalı vd. (2012) Kırıkkale Üniversitesi Mühendislik Fakültesi'nde destek bursu verilecek öğrenci seçimini yapmak için öğretim üyeleri ve öğrenciler ile beyin fırtınası yapılarak ölçütler belirlenmiş, AHP yöntemi kullanılarak ağırlıklar hesaplanmıș ve TOPSIS yöntemi kullanılması sonucunda seçim gerçekleștirilmiştir. Yayar ve Baykara (2012) Türkiye'deki gelișen katılım bankalarının 2005-2011 yıllarındaki faaliyetlerinin etkinlik ve verimliliklerini TOPSIS yöntemi ile ölçerek değerlendirmișlerdir. Orçanlı ve Özen (2013) dijital okuma cihazı olan e-kitap okuyucu seçimine karar verilmesi sürecinde AHP ve TOPSIS yöntemlerini kullanmıșlardır. Çalıșmalarında öncelikle bir e-kitap okuyucunun sahip olması gereken kriterleri belirlemișler ve uzman görüșlerine bașvurarak en önemlilerini seçmișlerdir. Akyüz vd. (2015) İstanbul Menkul Kıymetler Borsası'nda ișlem gören ve seramik sektöründe faaliyet gösteren bir anonim șirketin 1999-2008 yılları arasındaki finansal performansını TOPSIS yöntemini kullanarak değerlendirmișlerdir. Ömürbek vd. (2015) çalıșmalarında kurumsal proje yönetim yazılımı geliștirmek için bilgi ișlem daire bașkanlığınca yararlanılacak programın tercihi için AHP ve TOPSIS yöntemlerini kullanarak kurum için en uygun araç seçeneğini belirlemișlerdir. Koyuncu ve Özcan (2015) ise çalıșmalarında, otomotiv sektöründeki bir firmada çalıșan personelin ișe alınma süreçlerini AHP ve TOPSIS yöntemleri ile değerlendirmișler, sonrasında ise çalıșanların altı aylık çalıșma süreleri sonrası yapılan performans değerlendirmeleri ile AHP ve TOPSIS yöntemleri ile elde edilen sonuçlar arasında karșılaștırma yapmıșlardır. Yaldır ve Özgür Polat (2016) Kamu kurum ve kurulușlarında kullanılması yasal zorunluluk haline gelen Elektornik Belge Yönetim Sisteminin seçiminde AHP, Bulank AHP ve TOPSIS yöntemleri uygulanarak en uygun alternatif seçimini gerçekleștirmișlerdir. Yacan (2016) yüksek lisans tezinde eğitim kalitesinin belirlenmesinde rol oynayan değișkenlerin önem derecesine göre ağırlıklarını belirleyerek bulanık AHP ve bulanık TOPSIS yöntemleri kullanmıșlardır. İki eğitim kurumu arasında karșılaștırma yapmış ve eğitim kalitesini etkileyen faktörleri değerlendirmiștir. Kantemir ve Özkil (2016) ise terörle mücadele kapsamında kullanılan teknolojik silahların bizzat terörle mücadelede görev almış personelin algılarına dayalı olarak belirlenmesi sonrasInda AHP ve TOPSIS yöntemleri kullanarak teröristle mücadelede uzman personel tarafından algılanan etkinliklerine göre harp silah, araç ve gereçlerinin sıralaması üzerine çalıșmıșlardır. Samut (2016) Ekonomik Kalkınma İșbirliği Örgütü (OECD) üyesi ülkelerin eğitim performanslarının AHP ve TOPSIS yöntemleri kullanılarak ülke sıralamaları elde edilmiștir. Elgün ve Așkınoğlu (2016) hem ulusal hem de uluslararası tașıma, dağıtım ve ilgili lojistik faaliyetlerin yerine getirildiği organize alanlar olan lojistik köy seçiminde, nicel verinin bulunması nedeniyle TOPSIS yöntemini kullanarak sonuca ulaşmışlardır.

Literatür taraması sonucunda çok ölçütlü karar verme yöntemlerinin son yıllarda çeșitli alanlarda uygulandığı ve bu alanda yapılan çalıșmaların arttığı görülmektedir.

Bu çalıșmada karar verme sürecindeki olumsuz durumları engellemek ve seçim sürecini hızlandırmak için burs alacak inti- 
yaç sahibi ve bașarılı öğrencilerin seçimi, çok kriterli karar verme yöntemlerinden olan Analitik Hiyerarși Süreci (AHP) ve TOPSIS yöntemleri kullanılarak yapılmıștır.

Çalıșmanın ikinci bölümünü çok kriterli karar verme yöntemlerinden AHP ve TOPSIS yöntemleri oluștururken, üçüncü bölümde ise örnek uygulama ve elde edilen bulgular üzerinde durulmuștur. Son bölümde ise, çalıșma sonuçları değerlendirilip gelecekte yapılacak çalıșmalar hakkında bilgi verilmiștir.

\section{1. ÇOK ÖLÇÜTLÜ KARAR VERME YÖ́NTEMLERI}

Bu çalıșmada TEV bursu verilecek uygun adayın belirlenmesinde iki aşamalı çok kriterli karar verme yöntemi kullanılmıștır. Çalıșmanın ilk aşamasında kriterlerin ağırlıkları AHP yöntemi ile belirlenmiș, belirlenen ağırlıklar TOPSIS yöntemi kullanılarak performans sıralaması elde edilmiștir.

\subsection{AHP}

\section{(Analitik Hiyerarși Süreci)}

Çok kriterli karar verme yöntemlerinden biri olan Analitik Hiyerarși Süreci (AHP) Thomas L. Saaty (1980) tarafından geliștirilmiş matematiksel bir yöntemdir. Hiyerarșik bir yapı gösteren yaklașım, faktörlerin derecelerine göre düzenlendiği çok kriterli bir karar verme yöntemidir. Te- orinin ilkeleri ve felsefesi, kullanılan ölçüm türünün genel arka plan bilgisini, özelliklerini ve uygulamalarını özetler niteliktedir (Saaty, 1980). AHP yöntemi, çok sayıda karar vericinin çok sayıda farklı seçenek arasından seçim yapması durumunda kullanılabilen çok kriterli ve çok amaçlı bir karar verme yaklașımıdır (Saat, 2000; Örücü, 2008). Kararı etkileyen faktörleri ağırlıklar ile derecelendiren AHP yöntemi sayesinde, değișkenler arasındaki önem ilișkileri kuvvetlerine göre kurulabilmektedir.

AHP yönteminin aşamaları incelendiğinde karar veren kișinin amacına bağlı olarak ilk adım, faktörlerin ve bunların ilișkili oldukları alt değișkenlerin belirlenmesinden olușmaktadır. Bu așamada seçimin başarılı olabilmesi için önemli rolleri üstlenen faktörlerin seçiminin iyi yapılması gerekmektedir. Seçici değișkenler problemin çözümünü en iyi şekilde açıklayacak tarzda belirlenmeli gerekirse konusunda uzman kişilerin görüșleri alınmalıdır. İlk așama ile faktör ve bunlara bağlı alt faktörler belirlendikten sonra bunlar arasındaki ilișkilerin gücünün belirlenmesi gerekmektedir. Bu amaçla ikili karșılaștırma karar matrisleri kullanılabilir (Dağdeviren vd., 2004). Karar matrislerinin olușturulmasında Saaty (1980) tarafından önerilen 1-9 önem skalası kullanılır. İkili karșılaștırma karar matrisleri farklı kișilerin kararlarının

Tablo 1. Önem skalası tanımları

\begin{tabular}{|l|l|l|}
\hline Değer & Dereceler & Tanım \\
\hline 1 & Eşit önem & İki faktörde amaç için eșit önemde \\
\hline 3 & $\begin{array}{l}\text { Orta derecede } \\
\text { önem }\end{array}$ & Amaç için diğer faktöre göre orta derecede öneme sahip \\
\hline 5 & $\begin{array}{l}\text { Kuvvetli derecede } \\
\text { önem }\end{array}$ & Amaç için diğer faktöre göre daha kuvvetli öneme sahip \\
\hline 7 & $\begin{array}{l}\text { Cok kuvvetli } \\
\text { derecede önem }\end{array}$ & Amaç için diğer faktöre göre belirgin şekilde öneme sahip \\
\hline 9 & $\begin{array}{l}\text { Mutlak derecede } \\
\text { önem }\end{array}$ & Amaç için diğer faktöre göre kesin öneme sahip \\
\hline $2,4,6,8$ & Ara değerler & Amaç için diğer faktöre göre yakın öneme sahip \\
\hline
\end{tabular}


birleștirilmesi ile de olușturulabilir. Bunun için verilecek kararın birçok kişiyi etkileyecek yapıda olması gerekir. Bu yapıdaki ikili karșılaștırma matrisleri geometrik ortalama yöntemi ile daha tutarlı elde edilebilmektedir. Saaty (1980)'nin önerdiği 1-9 skalası en iyi sonuçların elde edilmesi için kullanılmaktadır (Dağdeviren vd., 2004). Tablo l'de önem skalası değerleri, dereceleri ve anlamları verilmiștir.

Olușturulan ikili karar matrislerine ait özdeğer ve özvektörler, hangi değișkenin daha güçlü olduğunu belirlemede ve buna göre öncelik sırasının olușturulmasında kullanılmaktadır. Diğer bir adım olarak, ikili karșılaștırma karar matrislerinden elde edilen bilgiler ile ağırlık vektörlerinin hesaplanması aşaması yer almaktadır. AğırIık vektörünün bulunması için öncelikle normalize edilmiş matrisin hesaplanması gerekmektedir. Bunun için, her bir sütun değeri ayrı ayrı ilgili sütun değeri toplamına bölünür. Daha sonra normalleștirilmiș matristeki her bir satır değerlerinin ortalaması alınır. Bulunan bu ortalama değerler her bir faktör için ağırlık vektörünü ifade etmektedir (Dağdeviren vd., 2004). AHP yöntemine ait hiyerarșik yapı Șekil 1'de görülmektedir.
Ağırlık vektöründeki değerlerin tutarlı olup olmadıklarının belirlenmesinde tutarIılık analizinden yararlanılmaktadır. Tutarlılık oranı (CR)'nin hesaplanabilmesi, faktör sayısı (n) ile temel değer adı verilen $(\lambda)$ katsayısının karșılaștırıımasına dayanmaktadır. $\lambda$ değerinin hesaplanması için öncelikle karșılaștırma matrisi ile ağırlık vektörünün matris çarpımı yapılıp sütun vektörü elde edilir. Elde edilen sütun vektörü elemanlarının ağırlık vektörü elemanlarına bölünüp ortalamalarının alınmasıyla da $\lambda$ değeri bulunur. Tutarlılık göstergesi $(\mathrm{Cl}), \lambda$ nın yardımıyla Eșitlik (1)'deki gibi bulunur.

$C I=\frac{\lambda-n}{n-1}$

Tutarlılık oranı olan CR'nin elde edilmesi için; tutarlılık göstergesi random gösterge (RI) değerine bölünür. Yapılan karşılaștırmanın tutarlı olup olmadığının belirlenmesi için, CR değerinin 0.10 değerinden küçük olması gerekmektedir (Karaatlı vd. 2014).

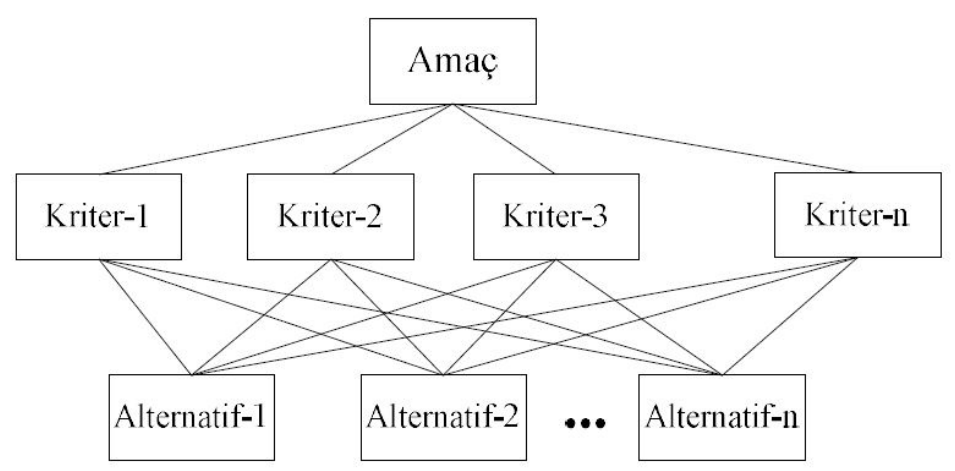

Șekil 1. Hiyerarșik yapı (Supçiller ve Çapraz 2011:7) 
Tablo 2. Random gösterge değerleri

\begin{tabular}{|c|c|c|c|c|c|c|c|c|c|c|}
\hline $\mathbf{n}$ & $\mathbf{1}$ & $\mathbf{2}$ & $\mathbf{3}$ & $\mathbf{4}$ & $\mathbf{5}$ & $\mathbf{6}$ & $\mathbf{7}$ & $\mathbf{8}$ & $\mathbf{9}$ & $\mathbf{1 0}$ \\
\hline $\mathrm{RI}$ & 0.00 & 0.00 & 0.58 & 0.90 & 1.12 & 1.24 & 1.32 & 1.41 & 1.45 & 1.49 \\
\hline $\mathrm{n}$ & 11 & 12 & 13 & 14 & 15 & \multicolumn{1}{|l}{} \\
\cline { 1 - 5 } $\mathrm{RI}$ & 1.51 & 1.48 & 1.56 & 1.57 & 1.59 & & & & & \\
\end{tabular}

\subsection{TOPSIS}

Çok kriterli seçim gerektiren uygulamalarda, seçiminin doğru bir șekilde yapılabilmesi için karar vericinin birçok faktörü objektif bir șekilde değerlendirmesi gerekmektedir. Bu zor süreçte, alternatiflerin belirli kriterlere göre değerlendirilebilmesi için çok kriterli karar verme yöntemlerinden biri genellikle tercih edilir (Șimșek vd., 2015). TOPSIS yönteminden çok kriterli karar verme problemlerinin çözümünde yararlanılmaktadır (Akyüz vd., 2011). İdeal pozitif çözümden en kısa mesafe ve negatif ideal çözümden en uzak mesafe alternatiflerinin seçimine dayanan bu teknik, Hwang ve Yoon (1981) tarafından geliștirilmiștir. TOPSIS yöntemi ile karar vericinin seçmiş olduğu alternatif, ideal sonuca en yakın ve negatif-ideal sonuca en uzak olan seçenektir (Yayar ve Baykara, 2012).

TOPSIS yönteminin aşamaları incelendiğinde ilgilenilen amaç hakkında değerlendirme kriterleri olușturulduktan sonra, karar matrisi olușturulur. Karar matrisi olușturulurken satırlarda seçim alternatifleri bulunurken, sütunlarda ise karar vermede kullanılacak faktörlere ait önem derecelerini ifade eden puanlar yer almaktadır. Sonraki adım olarak, karar matrisindeki her sütunda yer alan kriterin önem puanlarının, bu puanların kareleri toplamının kareköküne bölünmesiyle normalize ișlemi gerçekleștirilir. Normalize işlemi ile elde edilen karar matrisinin her bir elemanı ilgili faktörün önem derecesi ile çarpılarak normalize edilmiş ağırlıkı karar matrisi olușturulur (Koyuncu, 2015). Daha sonra, ideal pozitif çözüm ile ideal negatif çözüm oluşturulur. İdeal pozitif çözüm ağırlıklı normalize edilmiș en yüksek puanı alan alternatifi ifade ederken, ideal negatif çözüm ise en az puan alan en uzak alternatifi ifade eder. Son adım ise alternatiflerin göreli yakınlıklarına göre sıralanması ișlemidir. Bu sıralama bize en iyi alternatifleri göstermektedir.

\section{BURS VERILECEK ÖĞRENCILERIN BELIRLENMESI}

2016-2017 Eğitim-öğretim döneminde Mehmet Akif Ersoy Üniversitesi Eğitim Fakültesi'nde halen öğrenim görmekte olup Türk Eğitim Vakfından (TEV) burs almak isteyen başarılı ve intiyaç sahibi üç öğrenciye burs verilecektir. Bu çalıșmada, burs için başvuruda bulunan 27 adaya çok kriterli karar verme yöntemlerinden olan AHP ve TOPSIS uygulanarak burs verilecek öğrenciler belirlenmeye çalıșılmıștır. Öncelikle adaylara ait ölçütler belirlenmiș, daha sonra AHP yöntemi ile ölçütlerin ağırlıkları hesaplanmıștır. Son olarak hesaplanan ağırlıklar yardımı ile TOPSIS yöntemi kullanılarak burs alacak uygun adaylar belirlenmeye çalıșılmıştır.

\section{1. Ölçütlerin Belirlenmesi}

Burs verilecek öğrencilerin seçiminde etkili olacak ölçütler TEV tarafından açıklanan șartlar ile bașvuruda bulunan öğrencilerin bașvuru formlarında bulunan bilgiler değerlendirilerek olușturulmuștur. Ölçütlerin belirlenmesinde Abalı vd. (2012)'nin 
çalıșmalarında kullandıkları ölçütlere ek olarak seçimi gerçekleștiren uzmanlar ile de sözlü görüșme yapılıp bilgi alınarak ölçütler belirlenmiștir. Buna göre öğrencinin yaşı, cinsiyeti, sınıfı, başarısız ders sayısı, ÖSYM sıralaması, anne ve baba durumu, ailenin bakmakla yükümlü olduğu çocuk sayısı, ailenin yıllık geliri ve ailesinin mülk durumu bilgileri ölçüt olarak kabul edilmiș olup Tablo 3 'te yer almaktadır. nüldüğünde kararın bireylere bırakılmasının ne kadar karmașık ve zor bir seçim süreci olușturacağı da görülmektedir. Sağııklı bir seçim için ölçütlerin ağırlıklarının iyi belirlenmesi gerekmektedir.

Tablo 3. Ölçütler ve açıklamaları

\begin{tabular}{|c|c|c|}
\hline $\begin{array}{c}\text { Ölçüt } \\
\text { no }\end{array}$ & Ölçüt Adı & Ölçüt Açıklaması \\
\hline 1 & Öğrencinin Yașı (Y) & Öğrenim gören öğrencinin yașını göstermektedir. \\
\hline 2 & Öğrencinin Cinsiyeti (C) & Öğrenim gören öğrencinin Erkek veya Kadın olmasıdır. \\
\hline 3 & Öğrencinin Sınıfı (S) & $\begin{array}{l}\text { Öğrencinin halen öğrenim görmekte olduğu sınıfı } \\
\text { göstermektedir. }\end{array}$ \\
\hline 4 & $\begin{array}{l}\text { Öğrencinin başarısız } \\
\text { ders sayısı (BDS) }\end{array}$ & $\begin{array}{l}\text { Öğrencinin aldığı derslerden bașarısız olduğu ders } \\
\text { sayısını göstermektedir. }\end{array}$ \\
\hline 5 & $\begin{array}{l}\text { Öğrencinin ÖSYM } \\
\text { sıralaması (ÖSYMS) }\end{array}$ & $\begin{array}{l}\text { Öğrencinin yerleștiği yıldaki ÖSYM sıralamasını } \\
\text { göstermektedir. }\end{array}$ \\
\hline 6 & $\begin{array}{l}\text { Öğrencinin Anne ve } \\
\text { Baba durumu (ABD) }\end{array}$ & $\begin{array}{l}\text { Öğrencinin anne ve babasının sağ ya da vefat } \\
\text { etmiş veya evli ya da boșanmış olması durumunu } \\
\text { göstermektedir. }\end{array}$ \\
\hline 7 & $\begin{array}{l}\text { Öğrencinin ailesinin } \\
\text { bakmakla yükümlü } \\
\text { olduğu çocuk sayısı } \\
\text { (ABYOÇS) }\end{array}$ & $\begin{array}{l}\text { Öğrencinin ailesinin bakmakla yükümlü olduğu } 18 \\
\text { yaşından küçük veya } 25 \text { yaşını doldurmamış öğretim } \\
\text { gören çocuklarını ifade etmektedir. }\end{array}$ \\
\hline 8 & $\begin{array}{l}\text { Öğrencinin ailesinin yıllık } \\
\text { geliri (AYD) }\end{array}$ & $\begin{array}{l}\text { Öğrencinin çalıșan anne ve babasının yıllık gelir } \\
\text { durumunu göstermektedir. }\end{array}$ \\
\hline 9 & $\begin{array}{l}\text { Öğrencinin ailesinin } \\
\text { mülk durumu (AMD) }\end{array}$ & $\begin{array}{l}\text { Öğrencinin ailesinin maddi durumunu gösterir sahip } \\
\text { olduğu mülk (ev, arsa, araç vb.) durumunu ifade } \\
\text { etmektedir. }\end{array}$ \\
\hline
\end{tabular}

Ölçütler belirlenirken sonuca en çok etki edebilecek durumlar göz önüne alınmıștır. Özellikle ekonomik durumu ifade eden ve konu ile ilgisi olan etmenler dikkate alınırken, burs alımı ile ilgili olmayan bilgiler çalıșmaya dâhil edilmemiștir.

Tablo 3’te de görüldüğü gibi 9 adet ölçüt kullanılmış olup, bu bilgilerin burs alacak adayı belirlemede yeterli olacağı düșünülmüștür. Ayrıca burs alacak adayı belirlemeye etki eden faktör sayısı düșü-

\subsection{AHP Yöntemi ile Ölçütlerin Ağırlıklarının Belirlenmesi}

Burs için başvuruda bulunan adaylara ait ölçütler belirlendikten sonra AHP yöntemi ile bu ölçütler arasındaki ağırlıklar bulunmuștur. Ağırlıkların tespit edilmesi ișlemi için öncelikle hiyerarșik yapı olușturulmuș sonrasında ise ölçütlerin önem derecelerinin belirlenmesi için Saaty (1980) tarafından önerilen "1-9 ölçeği" önem 
Tablo 4. Ölçütler ve açıklamaları

\begin{tabular}{|c|c|c|}
\hline Ölçütler & Değerler & $\begin{array}{l}\text { Önem } \\
\text { Ölçeği }\end{array}$ \\
\hline \multirow{5}{*}{$A B D$} & Sağ Beraber & 1 \\
\hline & Sağ Ayrı & 3 \\
\hline & Baba Vefat & 5 \\
\hline & Anne Vefat & 7 \\
\hline & $\begin{array}{l}\text { Anne ve } \\
\text { Baba Vefat }\end{array}$ & 9 \\
\hline \multirow{5}{*}{ ABYOÇS } & 1 & 1 \\
\hline & 2 & 3 \\
\hline & 3 & 5 \\
\hline & 4 & 7 \\
\hline & $5+$ & 9 \\
\hline \multirow{4}{*}{ AMD } & Ev + Arsa & 1 \\
\hline & Sadece Ev & 3 \\
\hline & Kira + Arsa & 5 \\
\hline & Sadece Kira & 9 \\
\hline \multirow{5}{*}{ AYG } & $0-8400$ & 9 \\
\hline & $8401-16800$ & 7 \\
\hline & $\begin{array}{l}16801- \\
25200\end{array}$ & 5 \\
\hline & $\begin{array}{l}25201- \\
33600\end{array}$ & 3 \\
\hline & $33601+$ & 1 \\
\hline \multirow{5}{*}{ ÖSYMS } & $1-20000$ & 9 \\
\hline & $\begin{array}{l}20001- \\
35000\end{array}$ & 7 \\
\hline & $\begin{array}{l}35001- \\
50000\end{array}$ & 5 \\
\hline & $\begin{array}{l}50001- \\
150000\end{array}$ & 3 \\
\hline & $150001+$ & 1 \\
\hline \multirow{4}{*}{ BDS } & 0 & 9 \\
\hline & 1 & 6 \\
\hline & 2 & 4 \\
\hline & 3 & 1 \\
\hline
\end{tabular}

Tablo 4. Ölçütlerin önem skalası (Devam)

\begin{tabular}{|c|c|c|}
\hline Ölçütler & Değerler & $\begin{array}{l}\text { Önem } \\
\text { Ölçeği }\end{array}$ \\
\hline \multirow{6}{*}{$\mathrm{S}$} & 0 & 1 \\
\hline & 1 & 3 \\
\hline & 2 & 5 \\
\hline & 3 & 7 \\
\hline & 4 & 9 \\
\hline & 5 & 1 \\
\hline \multirow{2}{*}{ C } & Erkek & 1 \\
\hline & Bayan & 3 \\
\hline \multirow{9}{*}{$Y$} & 17 & 9 \\
\hline & 18 & 7 \\
\hline & 19 & 5 \\
\hline & 20 & 3 \\
\hline & 21 & 1 \\
\hline & 22 & 9 \\
\hline & 23 & 7 \\
\hline & 24 & 5 \\
\hline & $25+$ & 3 \\
\hline
\end{tabular}

skalası kullanılmıștır. TEV bașvuru ve değerlendirme verileri göz önünde bulundurularak belirlenen ölçütlerin önem skalası Tablo 4'teki gibidir. Daha sağlıklı seçim yapabilmek adına ölçütlerin önem skalası değerleri mümkün olduğunca detaylandırılıp kategori sayıları arttırımıștır.

Tablo 3 ve Tablo 4'teki verilen ölçüt ve değerler kullanılarak TEV bursuna bașvuru yapabilecek adaylarda aranan şartlar ile bașvuruda bulunamayacak öğrencilerin durumları düşünülerek değerlendirme yapıımıș ve ikili karșılaștırma matrisi olușturulmuștur. Ölçütlere ait karșılaștırma matrisi Tablo 5'te görülmektedir.

Karșılaștırma matrisi olușturulduktan sonra ölçütlerin ağırlık vektörünün oluşturulması için normalleștirme ișlemi ya- 
Tablo 5. Ölçütlerin karşılaștırma matrisi

\begin{tabular}{|l|c|c|c|c|c|c|c|c|c|}
\hline & $\mathbf{Y}$ & $\mathbf{C}$ & $\mathbf{S}$ & BDS & ÖSYMS & ABD & ABYOÇS & AYG & AMD \\
\hline $\mathbf{Y}$ & 1 & 2 & 0.33 & 0.2 & 0.25 & 0.143 & 0.166 & 0.111 & 0.125 \\
\hline $\mathbf{C}$ & 0.5 & 1 & 0.5 & 0.2 & 1 & 0.166 & 0.2 & 0.111 & 0.125 \\
\hline $\mathbf{S}$ & 3 & 2 & 1 & 0.33 & 2 & 0.143 & 0.143 & 0.111 & 0.143 \\
\hline BDS & 5 & 5 & 3 & 1 & 2 & 0.166 & 0.143 & 0.125 & 0.166 \\
\hline ÖSYMS & 4 & 1 & 0.5 & 0.5 & 1 & 0.125 & 0.143 & 0.111 & 0.166 \\
\hline ABD & 7 & 6 & 7 & 6 & 8 & 1 & 2 & 0.333 & 0.5 \\
\hline ABYOÇS & 6 & 5 & 7 & 7 & 7 & 0.5 & 1 & 0.5 & 1 \\
\hline AYG & 9 & 9 & 9 & 8 & 9 & 3 & 2 & 1 & 2 \\
\hline AMD & 8 & 8 & 7 & 6 & 6 & 2 & 1 & 0.5 & 1 \\
\hline
\end{tabular}

Tablo 6. Ölçütlerin ağırlık vektörü

\begin{tabular}{|c|c|c|c|c|c|c|c|c|c|}
\hline Ölçütler & Y & C & S & BDS & ÖSYMS & ABD & ABYOÇS & AYG & AMD \\
\hline Ağırlıklar & 0.023 & 0.022 & 0.036 & 0.059 & 0.032 & 0.176 & 0.164 & 0.294 & 0.194 \\
\hline
\end{tabular}

pılmıștır. Normalize edilmiş matris, her bir sütun değerinin ayrı ayrı ilgili sütun değeri toplamına bölünmesiyle elde edilmiștir. Normalize edilmiş karșılaștırma matrislerindeki satır değerlerinin ortalaması, ağırlıkların belirlenmesinde kullanılmıștır. Ağırlık matrisleri ile bu ağırlıkların ilișkili oldukları ölçüte ait karșılaștırma matrisinin çarpılması ile ağırlık vektörü olușturulmuștur (Abalı,2012). İșlem sonucu elde edilen ağırlık vektörü Tablo 6'da verilmiștir.

Tablo 6'da hesaplanan ağrılık vektörü değerlerinin tutarlı olup olmadığı tutarlılık analizi ile test edilmiștir. Temel değer olan $\lambda, 9.923$ olarak hesaplanmıs olup, $\mathrm{Cl}$ değeri ise Eșitlik (1) yardımı ile 0.115 bulunmuștur. Hesaplanan tutarlılık oranlarını ifade eden CR değeri ise 0.079 olup, 0.10 değerinden küçük olduğu için bulunan ağırlıklar tutarlıdır. Ağırlıklar belirlendikten sonra adayların nihai sıralamasının belirlenmesi için TOPSIS yöntemi kullanıımıștır.

\subsection{TOPSIS Yöntemi Uygulama Adımları ile Seçimin Sonuçlandırılması}

AHP yöntemi ile oluşturulan seçim alternatifleri ve kriter ölçütleri kullanılarak karar matrisi olușturulur. Karar matrisi olușturulurken satırlarda seçim alternatifleri yer alırken, sütunlarda ise karar vermede kullanılacak kriter ölçütlerinin aldığı önem puanları bulunur. Alternatifler göz önüne alınarak olușturulmuș karar matrisi Tablo 7'de verilmiștir.

Karar matrisindeki her sütunda yer alan kriterin önem puanlarının kareleri toplamının karekökü alınarak normalize edilmek istenen değere bölünmesi ile normalizasyon ișlemi yapılmıștır. Normalize ișlemi ile elde edilen karar matrisinin her bir elemanının ilgili faktörün ağırlık derecesi ile çarpııması ile normalize edilmiș ağırlıkı karar matrisi olușturulmuștur. İdeal pozitif çözüm ağırııkı normalize edilmiş en yüksek puanı alan alternafi ifade etmektedir. 
Tablo 7. Karar matrisi

\begin{tabular}{|c|c|c|c|c|c|c|c|c|c|}
\hline Sira No & $\mathbf{Y}$ & C & $\mathbf{S}$ & BDS & ÖSYMS & ABD & ABYOÇS & AYG & AMD \\
\hline 1 & 8 & 9 & 8 & 9 & 5 & 3 & 9 & 7 & 9 \\
\hline 2 & 6 & 9 & 5 & 9 & 7 & 1 & 1 & 3 & 3 \\
\hline 3 & 7 & 9 & 8 & 9 & 3 & 1 & 0 & 5 & 9 \\
\hline 4 & 8 & 9 & 8 & 9 & 7 & 1 & 0 & 7 & 3 \\
\hline 5 & 8 & 9 & 8 & 9 & 9 & 1 & 3 & 7 & 3 \\
\hline 6 & 4 & 9 & 5 & 6 & 3 & 1 & 0 & 3 & 9 \\
\hline 7 & 9 & 9 & 9 & 9 & 1 & 1 & 1 & 7 & 9 \\
\hline 8 & 5 & 9 & 3 & 9 & 1 & 1 & 0 & 5 & 5 \\
\hline 9 & 8 & 9 & 9 & 9 & 1 & 1 & 1 & 5 & 5 \\
\hline 10 & 7 & 7 & 8 & 9 & 1 & 1 & 1 & 5 & 9 \\
\hline 11 & 5 & 9 & 5 & 9 & 7 & 1 & 3 & 7 & 9 \\
\hline 12 & 2 & 9 & 3 & 9 & 1 & 1 & 7 & 7 & 3 \\
\hline 13 & 5 & 7 & 8 & 9 & 1 & 1 & 5 & 9 & 9 \\
\hline 14 & 5 & 7 & 7 & 9 & 5 & 1 & 3 & 5 & 3 \\
\hline 15 & 6 & 9 & 5 & 9 & 3 & 1 & 1 & 7 & 9 \\
\hline 16 & 4 & 7 & 3 & 9 & 1 & 1 & 1 & 5 & 3 \\
\hline 17 & 8 & 7 & 8 & 9 & 5 & 1 & 5 & 0 & 3 \\
\hline 18 & 8 & 7 & 8 & 9 & 3 & 1 & 3 & 5 & 9 \\
\hline 19 & 7 & 9 & 7 & 6 & 1 & 1 & 3 & 5 & 1 \\
\hline 20 & 8 & 9 & 9 & 9 & 9 & 1 & 0 & 9 & 3 \\
\hline 21 & 8 & 7 & 8 & 9 & 5 & 1 & 1 & 5 & 9 \\
\hline 22 & 6 & 7 & 8 & 9 & 3 & 1 & 1 & 7 & 3 \\
\hline 23 & 8 & 9 & 8 & 9 & 1 & 1 & 3 & 7 & 3 \\
\hline 24 & 6 & 9 & 5 & 9 & 7 & 1 & 1 & 1 & 9 \\
\hline 25 & 6 & 7 & 5 & 1 & 9 & 1 & 1 & 3 & 9 \\
\hline 26 & 9 & 9 & 8 & 9 & 3 & 1 & 3 & 1 & 3 \\
\hline 27 & 4 & 9 & 3 & 9 & 1 & 1 & 3 & 9 & 3 \\
\hline
\end{tabular}


Son olarak alternatiflerin göreli yakınIıklarına göre sıralanması ișlemi yapılmıștır. AHP ve TOPSIS yöntemi uygulanması sonucunda elde edilen göreli yakınlıklar Tablo 8' de verilmiștir. süreçte önemlidir. Örnek çalıșmada burs bașvurusunda bulunan öğrencilere ait ölçütlerin ağırlıkları AHP yöntemi kullanılarak belirlenmiş daha sonra bu ağırlıklarında yardımıyla TOPSIS yöntemi kullanılarak

Tablo 8. Göreli yakınlıklar

\begin{tabular}{|c|c|c|c|}
\hline Ögrenci no & Göreli Yakınlık & Öğrenci no & Göreli Yakınlık \\
\hline Ögrenci 1 & 0.87269 & Ögrenci 15 & 0.44692 \\
\hline Ögrenci 2 & 0.22616 & Ögrenci 16 & 0.31206 \\
\hline Ögrenci 3 & 0.36935 & Ögrenci 17 & 0.31295 \\
\hline Ögrenci 4 & 0.37603 & Ögrenci 18 & 0.44246 \\
\hline Ögrenci 5 & 0.44915 & Ögrenci 19 & 0.35455 \\
\hline Ögrenci 6 & 0.30762 & Ögrenci 20 & 0.43747 \\
\hline Ögrenci 7 & 0.44730 & Ögrenci 21 & 0.38933 \\
\hline Ögrenci 8 & 0.31492 & Ögrenci 22 & 0.39292 \\
\hline Ögrenci 9 & 0.33530 & Ögrenci 23 & 0.44541 \\
\hline Ögrenci 10 & 0.38772 & Ögrenci 24 & 0.28326 \\
\hline Ögrenci 11 & 0.50223 & Ögrenci 25 & 0.32617 \\
\hline Ögrenci 12 & 0.56820 & Ögrenci 26 & 0.23211 \\
\hline Ögrenci 13 & 0.60426 & Ögrenci 27 & 0.50125 \\
\hline Ögrenci 14 & 0.37332 & & \\
\hline
\end{tabular}

TOPSIS yöntemi ile göreli yakınlıkların bulunması burs alacak öğrencilerin seçim sürecini kolaylaștırıp daha objektif bir değerlendirilmesini sağlamaktadır. Elde edilen sonuçlar incelendiğinde de öğrencilerin göreli yakınlıkların ifade ettiği tek değișkenli veriler ile ifade edilebilmesi sonucu seçim süreci kolay bir șekilde gerçekleștirilebilmiștir.

\section{SONUÇ VE ÖNERILER}

Ülkemizde intiyaç sahibi başarılı öğrencilere burs veren pek çok kurum ve kuruluş bulunmaktadır. Başvuru ve değerlendirme așamasında hem kâğıt israfı meydana gelmekte hem de zaman kaybı yaşanmaktadır. Değerlendirme yapan görevlilerin objektif karar vermeleri de bu en uygun öğrenci seçimi yapılmıștır. Elde edilen bulgularda CR değeri 0.079 bulunmuş olup ağırlıkların tutarlı olduğu tespit edilmiștir. TOPSIS yöntemi ile elde edilen bulgular incelendiğinde en yüksek göreli yakınlık değerlerine sahip 3 alternatif belirlenmiș olup, burs verilecek en uygun adayların seçimi sağlanmıștır.

Burs veren kurum ve kurulușların bașvuruları internet üzerinden alması ve çok kriterli karar verme yöntemi ile seçim yapması halinde seçim sürecinde yașanan sorunlar azalıp daha objektif sonuçlar allnabilecektir. Illeride yapılacak çalıșmalarda AHP ve TOPSIS yöntemi kullanılarak Üniversitelerde en başarılı akademik personelin belirlenmesi gerçekleștirilebilir. 


\section{REFERENCES / KAYNAKLAR}

Abalı, Y., Kutlu, B. \& Eren, T. (2012). Çok Ölçütlü Karar Verme Yöntemleri Ille Bursiyer Seçimi: Bir Eğitim Kurumunda Uygulama. Atatürk Üniversitesi İktisadi ve İdari Bilimler Dergisi, 26 (3-4), 259-272

Akyüz, Y., Bozdoğan, T. \& Hantekin, E. (2015). TOPSIS Yöntemiyle Finansal Performansın Değerlendirilmesi ve Bir Uygulama. Afyon Kocatepe Üniversitesi İktisadi ve İdari Bilimler Fakültesi Dergisi, 13 (1), 73-92.

Dağdeviren, M., Akay, D. \& Kurt, M. (2004). Is Değerlendirme Sürecinde Analitik Hiyerarși Prosesi Ve Uygulaması. Gazi Üniversitesi Mühendislik-Mimarlık Fakültesi Dergisi, 19 (2), 131138.

Elgün, M. \& Așıkoğlu, N. (2016). Lojistik Köy Kuruluș Yeri Seçiminde Topsıs Yöntemiyle Merkezlerin Değerlendirilmesi. Afyon Kocatepe Üniversitesi İktisadi ve İdari Bilimler Fakültesi Dergisi, 18 (1), 161-170.

Erdem Hacıköylü, B. (2006). Analitik Hiyerarși Karar Verme Süreci ile Anadolu Üniversitesi'nde Beslenme ve Barınma Yardımı Alacak Öğrencilerin Belirlenmesi. Yayımlanmış Yüksek Lisans Tezi. Anadolu Üniversitesi, Sosyal Bilimler Enstitüsü, Eskișehir.

Gülenç, I.F. \& Aydın Bilgin, G. (2012). Yatıım Kararları İçin Bir Model Önerisi: Ahp Yöntemi. Öneri Dergisi, 9 (34), 97-107.

Günay, Z. \& Ünal, Ö. (2016). Selectıon Of Supplier With Ahp And Topsis (Sample Of A Telecomminication Firm In Turkey). PESA Uluslararası Sosyal Araștırmalar Dergisi, 2 (1), 37-53.

Kantemir, Ö. \& Özkil, A. (2016). Teröristle Mücadelede Kullanılan Silah Sistemlerinin Etkinliklerine Yönelik Algıların Belirlenmesi. Güvenlik Bilimleri Dergisi, 4 (2), 37-62.

Karaatlı, M., Ömürbek, N., Aksoy, E. \& Karakuzu, H. (2014). Turizm İșletmeleri İçin AHP Temelli Bulanık Topsis Yöntemi İle Tur Operatörü Seçimi. Anadolu Üniversitesi Sosyal Bilimler Dergisi, 14 (2), 53-70.
Koyuncu, O. \& Özcan, M. (2015). Personel Seçim Sürecinde Analitik Hiyerarși Süreci ve TOPSIS Yöntemlerinin Karșlaștırılması: Otomotiv Sektöründe Bir Uygulama. Hacettepe Üniversitesi İktisadi ve İdari Bilimler Fakültesi Dergisi, 32 (2), 195-218.

Kutlu, B., Abalı, Y. \& Eren, T. (2012). Çok Ölçütlü Karar Verme Yöntemleri İle Seçmeli Ders Seçimi. Kırıkkale Üniversitesi Sosyal Bilimler Dergisi, 2 (2), 5-25.

Orçanlı, K. \& Özen, Ü. (2013). The Implementation In Choosing E-Book Reader of Ahp and Topsis That Are The Methods Of Multi-Criteria Decision Making. Ușak Üniversitesi Sosyal Bilimler Dergisi, 15, 282-310.

Ömürbek, N., Makas, Y. \& Ömürbek, V. (2015). Ahp ve Topsıs Yöntemleri Ile Kurumsal Proje Yönetim Yazılımı Seçimi. Süleyman Demirel Üniversitesi Sosyal Bilimler Enstitüsü Dergisi, 21, 59-83.

Örücü, E., Aydın, G., Kızılgöl, Ö. \& Hasgül, Ö. (2008). Bandırma Limanının Etkinliğinin Arttırılması ve Bandırmanın Lojistik Merkez Haline Getirilmesine Yönelik Saha Çalıșması. Bandırma İktisadi Araștırmalar Enstitüsü, Yayın no:2.

Özyörük, B. \& Özcan, E.C. (2008). Analitik Hiyerarși Sürecinin Tedarikçi Seçiminde UygulanmasI: Otomotiv Sektöründen Bir Örnek. Süleyman Demirel Üniversitesi İktisadi ve İdari Bilimler Fakültesi Dergisi, 13 (1), 133-144.

Saat, M. (2000). Çok Amaçlı Karar Vermede Bir Yaklaşım: Analitik Hiyerarși Yöntemi. Gazi Üniversitesi Iktisadi ve İdari Bilimler Fakültesi Dergisi, 2 (2), 149-162.

Saaty, T.L. (1980). The Analytic Hierarchy Process. McGraw-Hill Interntional Book Company, New York.

Saaty, T.L. (1990). How to make a decision: the analytic hierarchy process. European Journal of Operational Research, 48, 9-26.

Samut, P. (2016). Anadolu Üniversitesi Sosyal Bilimler Dergisi iki Așamalı Çok Kriterli Karar Verme ile Performans Değerlendirmesi: AHP ve TOPSIS Yöntemlerinin Entegrasyonu. Anadolu Üniversitesi Sosyal Bilimler Dergisi, 14 (4), 57-67. 
Supçiller, A. \& Çapraz, O. (2011). AHP-TOPSIS Yöntemine Dayalı Tedarikçi Seçimi Uygulaması. Ekonometri ve İstatistik e-Dergisi, (12. Uluslararası Ekonometri, Yöneylem araștırması, İstatistik Sempozyumu Özel SayısI), 13, 1-22.

Șimșek, A., Çatır, O. \& Ömürbek, N. (2015). Topsis ve Moora Yöntemleri ile Tedarikçi Seçimi: Turizm Sektöründe Bir Uygulama. Balıkesir Üniversitesi Sosyal Bilimler Enstitüsü Dergisi, 18 (33), 133-161.

Yacan, I. (2016). Eğitim Kalitesinin Belirlenmesinde Etkili Olan Faktörlerin Bulanık AHP ve Bulanık TOPSis Yöntemi ile Değerlendirilmesi. Yayımlanmıș Yüksek Lisans Tezi. Pamukkale Üniversitesi, Sosyal Bilimler Enstitüsü, Denizli.

Yaldır, A. \& Polat, L.Ö. (2016). Çok Kriterli Karar Verme Teknikleri Ille Elektronik Belge Yönetim Sistemi Seçimi. Mehmet Akif Ersoy Üniversitesi Sosyal Bilimler Enstitüsü Dergisi, 8 (14), 88-108.

Yayar, R. \& Baykara, H.V. (2012). TOPSIS Yöntemi ile Katıım Bankalarının Etkinliği ve Verimliliği Üzerine Bir Uygulama. Business and Economics Research Journal, 3 (4), 21-42.

Yükseköğretim Kurulu Bașkanlığı (2016). Üniversite sayısı. Erișim tarihi:10.11.2016, http:// www.yok.gov.tr/web/guest/universitelerimiz. Yükseköğretim Kurulu Bașkanlığı (2016). Öğrenci sayısı. Erişim tarihi:10.11.2016, https://istatistik.yok.gov.tr. 